
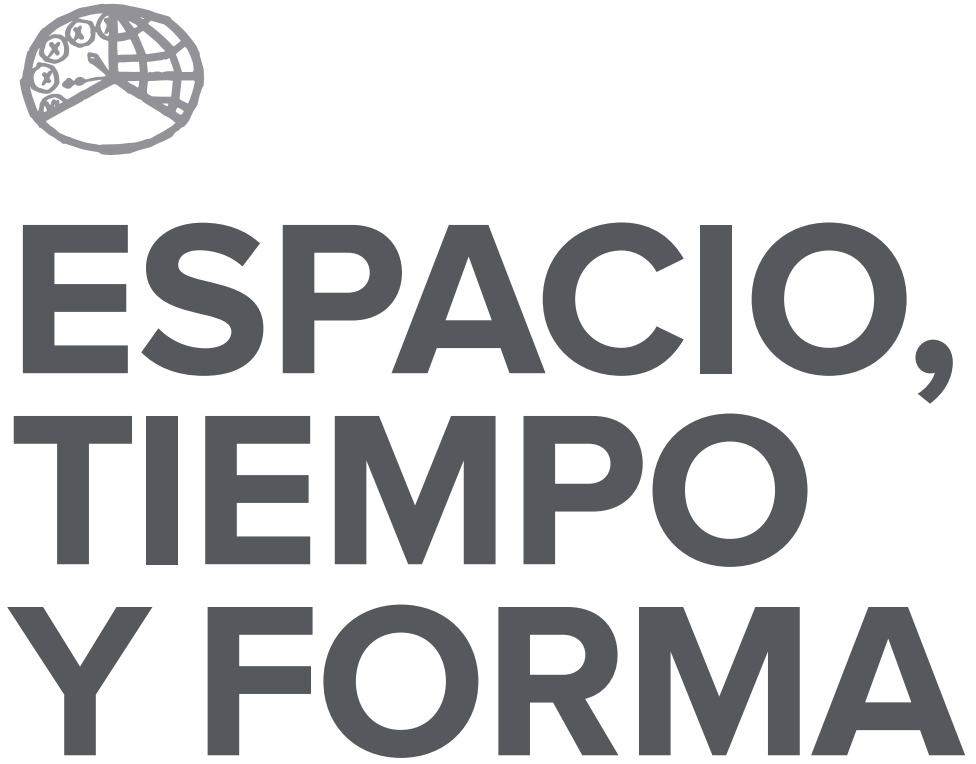

AÑO 2020

ISSN 0214-9745

E-ISSN 2340-1362

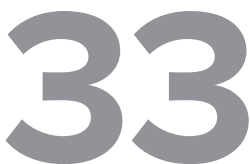

SERIE III HISTORIA MEDIEVAL

REVISTA DE LA FACULTAD DE GEOGRAFÍA E HISTORIA 



\section{ARTÍCULOS · ARTICLES}





\title{
ENTRE LOS SIGNOS DEL CIELO Y LAS VOCES DE LOS HOMBRES: LA VISIÓN MEDIEVAL DEL CIELO Y SU REPRESENTACIÓN APOCALÍPTICA
}

\author{
BETWEEN THE SIGNS OF HEAVEN \\ AND THE VOICES OF MEN: THE \\ MEDIEVAL VISION OF HEAVEN AND ITS \\ APOCALYPTIC REPRESENTATION
}

\author{
Mariana Valeria Parma ${ }^{1}$
}

Recepción: 2019/04/19 · Comunicación de observaciones de evaluadores: 2019/05/28 .

Aceptación: 2019/11/4

DOI: http://dx.doi.org/10.5944/etfiii.33.2020.24264

\section{Resumen}

El concepto de cielo adquirió múltiples significados en distintos contextos históricos. Asociado a la idea del más allá, la noción también remite a la esfera celeste donde se hallan los astros y la temática se vincula con las diversas representaciones del universo que se desplegaron a través de los tiempos. Las visiones celestes guardan estrecha relación con el contexto histórico en el que se imponen y particularmente con los fundamentos del orden social entonces vigente. En este artículo nos proponemos rastrear, desde una perspectiva de análisis de historia cultural, las representaciones del cielo imperantes en los tiempos medievales y en particular establecer la significación de la mirada apocalíptica. La particular ambivalencia de la apocalíptica cristiana funcionará como punto de partida para la ruptura de significados que produjo la lectura bajomedieval de estas ideas en el contexto crítico feudal con consecuencias decisivas para el orden social.

\section{Palabras clave}

Representaciones celestiales; apocalíptica; orden medieval; agustinismo; joaquinismo; milenarismo 


\begin{abstract}
The concept of heaven acquired multiple meanings in different historical contexts. Linked to the idea of the hereafter, the notion also refers to the celestial sphere where the stars are found and the theme is linked to various representations of the universe that developed throughout the ages. The celestial visions are closely related to the historical context in which they appear and particularly to the foundations of the prevailing social order of the time. In this article, we propose to trace the representations of heaven that prevailed in medieval times, from a cultural history approach, and in particular, to establish the meaning of the apocalyptic view. The particular ambivalence of Christian apocalyptics is a starting point for the transformation of meanings produced by late medieval readings of these ideas in a critical feudal context with decisive consequences for the social order.
\end{abstract}

Keywords

Celestial Representations; Apocalyptics; Medieval Order; Augustinianism; Joachimism; Millenarianism. 
En el fin del mundo, «el sol se oscurecerá, y la luna no dará su resplandor, y las estrellas caerán del cielo, y las potencias del cielo serán conmovidas».

(Evangelio de San Mateo) ${ }^{2}$.

En torno al concepto de cielo, múltiples significaciones se han registrado en todos los tiempos históricos y en las más diversas tradiciones culturales. Desde el punto de vista filosófico, como sinónimo del más allá, se encuentra en la mayoría de las religiones y en particular en la tradición judeocristiana fue concebido como morada de Dios, de los ángeles y de las almas humanas e incluso como destino final de la Humanidad. Pero a este cielo profético, podemos sumar aquel que representa a la esfera celeste, el espacio en el que se mueven los astros, donde se ubican y distribuyen el sol, las estrellas, los planetas, las constelaciones y la luna. Esta versión astronómica del concepto también acompañó y fue transformándose por el desarrollo humano. La astronomía y la profecía postulan una relación entre el tiempo y el conocimiento, donde la distancia en el tiempo aparece como requisito indispensable para toda nueva comprensión. ${ }^{3}$ En la intersección entre ambas se pueden reconocer una serie de imágenes o visiones celestes, cuya importancia guarda estrecha relación con el contexto histórico en el que se imponen y particularmente con los fundamentos del orden social entonces vigente.

En este artículo nos proponemos rastrear, desde la perspectiva de una historia cultural, las representaciones del cielo imperantes en los tiempos medievales y en particular establecer la significación de la mirada apocalíptica. La misma se ubica entre el presente y el futuro de la humanidad y sus postulados establecen una relación estrecha entre los signos del cielo y las voces de los hombres. ${ }^{4}$ Conforme a este objetivo, organizamos la presentación en tres secciones: en la primera, desarrollamos las herramientas conceptuales y características de la perspectiva de análisis desde la cual nos aproximamos a nuestro objeto de estudio. En segundo lugar, intentamos reconstruir las visiones celestes tanto las hegemónicas en el orden medieval como las que postuló la tradición apocalíptica. Finalmente, situamos en el contexto sociohistórico las representaciones escatológicas dando cuenta de las distintas significaciones que adquirieron en el contexto medieval como en el bajomedieval. La propuesta apocalíptica con sus perturbaciones, desplazamientos de sentido y ambivalencias discursivas con relación a la visión canónica medieval de los cielos, adquirió en la época particular trascendencia dentro del repertorio cultural de los privilegiados pero también de los dominados.

2. Evangelio de San Mateo (24-29), en ReinA, Casiodoro y VARela, Cipriano de: La Santa Biblia: Antiguo y Nuevo Testamento. Buenos Aires, Sociedades Bíblicas en América Latina, 1960, p. 904.

3. BuLL, Malcolm (comp.): La teoría del apocalipsis y los fines del mundo. México, FCE, 1998, p. 27.

4. WARBURG, Aby: El renacimiento del paganismo. Aportaciones a la historia cultural del Renacimiento europeo. Madrid, Alianza, 2005, p. 448. 


\section{LA HISTORIA CULTURAL COMO PERSPECTIVA METODOLÓGICA DE ANÁLISIS}

La aproximación metodológica a las representaciones celestes adopta una perspectiva de análisis desde la historia cultural, dado que centra su interés sobre las formas simbólicas, explicativas e ideológicas en el contexto histórico medieval y bajomedieval. La lectura contextual permite superar una visión de la historia limitada al simple desarrollo de prácticas discursivas. Rescatar la materialidad de la cultura preserva al historiador de los riesgos a los que conlleva la indagación social a partir del llamado «linguistic turn». Según esta tendencia teórica, el discurso no sólo representa la realidad, sino que también la construye y, por lo tanto, la sociedad no puede ser explicada a partir de grandes modelos sino que toda práctica o institución social es un texto que debe ser interrogado en sí mismo y como parte de un sistema de significación. De esta forma, se niegan los condicionamientos materiales e institucionales de la cultura y estas posturas derivan en un hiperrelativismo. Se anula, en definitiva, toda distinción entre historia y lenguaje. ${ }^{5}$ En la encrucijada entre lo literario y lo real, rescatamos el concepto sociológico de «campo» que postuló Pierre Bourdieu, que se construye a partir de un «capital simbólico» común, que comparten los sujetos participantes que interactúan para que esos bienes se produzcan, circulen y se consuman y aparece luego la lucha por su apropiación. La cultura se entiende como una herramienta para la reproducción social. ${ }^{6}$ Es el «habitus» de un determinado grupo social el que define la forma de apropiación o relación por parte del sujeto con el capital simbólico, noción que posee la gran ventaja de permitir a quien lo utiliza reconocer el ámbito de la libertad individual dentro de ciertos límites impuestos por la cultura».?

Partir de lo material en el estudio de los procesos históricos, que en este caso remiten a la construcción del régimen feudal hasta su primera crisis, permite asimismo evitar caer en una visón voluntarista, en la cual todo suceso o idea pueda ser concebido como subproducto de la acción del agente, independientemente de la situación histórica en la que se desarrolla y en este sentido los criterios de relación entre condiciones objetivas y el agente social se definen como una interiorización de la objetividad no controlada racionalmente. ${ }^{8}$ Esto es que adquiere una racionalidad práctica por interiorización de las condiciones en que está inmerso. En este sentido, el aporte de Ernesto Laclau y Chantal Mouffe, quienes parten de una perspectiva analítica de matriz gramsciana con aportes postestructuralistas

5. Benigno, Francesco: Espejos de la revolución. Conflicto e identidad política en la Europa moderna. Barcelona, Crítica, 2000, pp. 39-43.

6. Bourdieu, Pierre: La distinción: criterios y bases sociales del gusto. Madrid, Taurus, 1999

7. BURKE, Peter (ed.): Formas de hacer historia. Madrid, Alianza, 1994, pp. 34-35

8. Bourdieu, Pierre: El sentido práctico. Madrid, Taurus, 1991 
y lacanianos, concibe la «dimensión hegemónica» como constitutiva de la subjetividad de los agentes históricos. ${ }^{9}$

Entre las nociones conceptuales que construyen el presente artículo destacamos el concepto de circularidad de ideas de Carlo Ginzburg, en tanto remite al juego sutil de apropiaciones y cambios de sentido de objetos culturales. ${ }^{\text {Io }}$ También son fundamentales los aportes de la antropología cultural y particularmente los de Raymond Williams que desplazan la atención hacia las continuidades culturales y hacia la construcción de significados a partir de un stock cultural determinado. ${ }^{\text {II }}$ En este trabajo, empleamos las nociones de la historiografía cultural, discurso, práctica y representación, propuestas por Roger Chartier, que permiten relacionar producciones discursivas y prácticas sociales, siguiendo las premisas de Foucault, de Certeau y Marin. ${ }^{\mathrm{I2}}$ Trasladada al análisis semiótico, la idea de representación en sus dos acepciones permite distinguir en cualquier enunciado dos dimensiones (transparente-opaca) y entender un texto como una manifestación a la vez secreta y pública. Lo real, como objetivo histórico no es la realidad misma sino la forma en que se traduce dentro de la «historicidad de su producción» y la «estrategia de su escritura». El concepto niega la concepción de la literatura como espejo de la realidad social, ya que se constituye como interacción de representaciones en conflicto. ${ }^{13}$

Vinculada a esta última noción postulamos una última herramienta conceptual: la noción de «imaginarios sociales» de Bronislaw Baczko, concebidos como «representaciones de la realidad social y no simple reflejos de ésta. Inventados y elaborados con materiales sacados del fondo simbólico, tienen una realidad específica que reside en su misma existencia, en su impacto variable sobre las mentalidades y los comportamientos colectivos, en las múltiples funciones que ejercen en la vida social». ${ }^{14}$ Con estas herramientas metodológicas, nos adentramos a entender las formas de las representaciones celestiales en la Europa cristiana del medioevo hasta el estallido de su primera crisis.

\section{LAS REPRESENTACIONES CELESTES BAJO EL ORDEN MEDIEVAL}

En la Edad Media, el cielo adquirió múltiples significaciones como la ciudad eterna, la promesa del conocimiento de Dios y la promesa del amor de Cristo. ${ }^{15}$

9. LACLAU, Ernesto y MOUFFE, Chantal: Hegemonía y estrategia socialista. Hacia una radicalización de la democracia. Buenos Aires, FCE, 2004

10. GinzburG, Carlo: El queso y los gusanos. El cosmos según un molinero del siglo XVI. Barcelona, Muchnik, 1981, pp. 20-21.

11. Williams, Raymond: El campo y la ciudad. Buenos Aires, Paidós, 2001

12. Chartier, Roger: Escribir las prácticas. Foucault, de Certeau, Marin. Buenos Aires, Manantial, 1996, pp. 7-11.

13. ChARTIER, Roger: El mundo como representación. Historia cultural: entre práctica y representación. Barcelona, Gedisa, 1995, pp. 40-57.

14. BACZKo, Bronislaw: Los imaginarios sociales. Memorias y esperanzas colectivas. Buenos Aires, Nueva Visión, 1991, p. 8.

15. MCDAnnell, Collen y LANG, Bernhard: Historia del cielo. Madrid, Taurus, 2001 
Más allá de estas atribuciones simbólicas, la visión del universo que cristalizó durante el orden medieval hundía sus raíces en la Antigüedad grecorromana. Una cosmología antigua, transmitida en forma sesgada, postulaba un universo, ordenado en su interior, pero finito sin ambigüedades.$^{16}$ Se trataba de un cosmos medieval pequeño, centrado en la Tierra y cuya realidad era bella y armoniosa. Estaba limitado por un borde materializado por la esfera cristalina de las estrellas fijas que constituía la frontera del mundo. En su interior, la representación tradicional consagraba una jerarquía de esferas alrededor de la Tierra que incluía la de la Luna, la del Sol y la de los cinco planetas de Mercurio a Saturno. ${ }^{17}$ Esta estructura del cielo, el campo de las representaciones relevadas, se conformó en base a la astronomía teórica y no observacional, basada en el principio de la perfección, que desarrolló Platón en el Timeo. El texto pagano refería al proceso de creación del cielo por el Demiurgo o dios artesano, a partir de la contemplación del mundo de las ideas con sus prototipos de belleza, perfección y bondad. El mundo creado se concebía como único, por ser el más cercano a la perfección, y por lo tanto adquiría la forma más perfecta, la esférica. Constituía la más bella de todas las creaciones, producto del trabajo de la mejor de las causas, que utilizó para ello los cuatro elementos (fuego o luz, tierra, agua, aire) y las mezclas de lo mismo, lo otro y la esencia. Según la visión platónica, el movimiento de lo mismo (el de las estrellas fijas) y el movimiento de lo otro (el de los planetas) permitían la medición del tiempo. ${ }^{18}$ En Platón y también en Pitágoras se puede rastrear el concepto de la armonía de las esferas, inaudible a los mortales, a partir del movimiento de los astros por relaciones rítmicas con expresión numérica. ${ }^{19}$

En la circularidad sesgada de las representaciones celestes que caracterizó a los tiempos medievales, el Timeo de Platón y la visión pitagórica de un mundo organizado, a partir de principios básicos y proporciones regulares, definirán el imaginario social hasta la modernidad acerca de la estructura del cielo. La continuidad cultural de estas representaciones antiguas estuvo dada por obras tales como El sueño de Escipión de Cicerón o el comentario de Macrobio sobre la misma. En la obra ciceroniana del siglo I AC, el Escipión Emiliano despierta en la bóveda de las estrellas fijas y aparece un ancestro, el Escipión africano, quien le muestra la tierra, las esferas y el alma de los justos en las estrellas fijas. ${ }^{20}$ Los comentarios de Macrobio sobre este sueño reafirmaban el concepto de la armonía de las esferas, constituyendo el texto básico para la transmisión de la astronomía de la antigüedad al medioevo hasta la recuperación del aporte aristotélico

16. LEWIS, Clive Staples: La imagen del mundo: Introducción a la literatura medieval y renacentista. Barcelona, Península, 1997, pp. 81-84.

17. Gangul, Alejandro: El Big Bang. La génesis de nuestra cosmología actual. Buenos Aires, Eudeba, 2005, pp. 54-59.

18. Platón: Timeo. Buenos Aires, Colihue, 2005, pp. 27-45.

19. Gangui, Alejandro: Op. cit., pp. 39-43.

20. Cicerón, Marco Tulio: El sueño de Escipión. Barcelona, Acantilado, 2004 
hacia el siglo XII. ${ }^{21}$ A partir de este siglo, la Iglesia dominante adoptó la obra de Aristóteles que no entrañaba mayores dificultades para su conciliación con los postulados cristianos, ya que aseguraba la eternidad de un universo increado. En cuanto a los cielos, Aristóteles afirmaba en su tratado las características eternas e inmortales del mundo y, por tanto, su perfección con forma esférica, «desde siempre y por siempre». Este universo además se concebía como dotado de un movimiento eterno, natural y no violento, a partir del Primum Mobile o Primer Motor que se ubicaba más allá de las estrellas fijas. Este movimiento era diferenciado de los desplazamientos efímeros de los elementos en el mundo sublunar, dirigidos hacia su lugar natural: la tierra hacia el centro, el horizontal del agua sobre la superficie y hacia lo alto en el caso del fuego. La superficie interna del mundo, perfectamente pulida, alojaba a las estrellas fijas, esto es la condensación de la materia de la quinta esencia o éter, sustancia primordial de la región supralunar incorruptible e imponderable. Todas ellas se encontrarían a la misma distancia de la Tierra y más allá de ellas, no existía, según Aristóteles, ni el espacio ni el tiempo. ${ }^{22}$ Obra síntesis de la Antigüedad, Del cielo postulaba un cosmos eterno donde los cielos son eternamente iguales. ${ }^{23}$

Pero esta proposición de un mundo eterno chocaba de lleno con las afirmaciones bíblicas del Génesis, de allí su tardía adopción. ${ }^{24}$ El acervo cultural antiguo, incluyendo el aporte de Aristóteles, fue conservado y continuado por los árabes, mundo con el que entró en contacto la cristiandad a partir del siglo XI. Con las nacientes universidades europeas un siglo después y las traducciones al latín de las obras antiguas, se logró la síntesis entre la razón griega y la fe cristiana incorporando las nociones aristotélicas a la doctrina de la Iglesia. La reactualización selectiva del pasado clásico imponía adaptar la teoría astronómica a la observación de los fenómenos celestes. Un esfuerzo en esta dirección supuso la adopción del sistema ptolemaico; mecánica de los movimientos planetarios desarrolladas por Ptolomeo en el Almagesto. El sistema permitía la fusión de la corriente aristotélica de pensamiento y una astronomía del cálculo que tenía como principios el geocentrismo y la circularidad y por objetivos la búsqueda de un sistema homogéneo y unitario. Síntesis del legado astronómico antiguo, el Almagesto describía un sistema universal geocéntrico con cuerpos celestes girando en torno a una Tierra estática. ${ }^{25}$ Adoptado por el cristianismo, el universo ptolemaico definió un campo de representaciones que constituía una arquitectura con una Tierra esférica en su centro, rodeada de esferas transparentes superpuestas con cuerpos luminosos fijos: la Tierra, la Luna, Mercurio, Venus, el Sol, Marte, Júpiter y Saturno. Luego,

21. Macrobio: Comentario al sueño de Escipión. Madrid, Siruela, 2005

22. Aristóteles: Acerca del cielo. Madrid, Gredos, 1996, Libro II, c.9.

23. Gangul, Alejandro: Op. cit., pp. 59-62

24. Libro del Génesis, en Reina, Casiodoro y VARELA, Cipriano de: Op. cit., pp. 5-56.

25. Gangul, Alejandro: Op. cit., pp. 63-72. 
se encontraba el Stellatum, las estrellas fijas con posiciones invariables y, más allá, el Primum Mobile, cuya existencia era claramente inferida. Dios le comunicaba a este primer motor, poder y energía y engendraba un movimiento de rotación que se comunicaba desde las estrellas hasta la Luna. Esta construcción intelectual imperfecta, que exigió esfuerzos constantes para ajustarse a los fenómenos observados y mantenía con ellos discrepancias permanentes, se adaptó a la doctrina dominante y creó una imagen del cielo colmada de Dios y de luz, que coincidía con las ideas escolásticas de armonía y contemplación. ${ }^{26}$ Los valores guardaban estrecha relación con un imaginario social dominante que rechazaba la idea de cambio o mutación, que cristalizaba la inmutabilidad del sistema de dominación y la naturalización de las diferencias sociales, como reflejo del orden celestial.

La visión ordenada del cielo cristiano medieval, vigente hasta la irrupción de la revolución científica, encontró su representación paradigmática en la obra de Dante Alighieri, La Divina Comedia. Ninguna pieza tuvo la misma influencia sobre la visión de la organización del cosmos como esta obra, ya que sus imágenes terminaron por impregnar al conjunto de la literatura de la época. Escrita en italiano y no en latín, el libro narra el viaje del poeta por los tres reinos: infierno, purgatorio y paraíso. En el inicio, guiado por Virgilio, Dante penetraba el infierno en las entrañas de la tierra hasta su llegada al centro donde encuentra a Lucifer o emperador del reino doloroso y desde allí, se produce el ascenso al Purgatorio y por encima, al Jardín del Edén. En el cielo, Beatriz relevaba a Virgilio en la tarea y condujo a Dante a través de la esfera de fuego y por las sucesivas esferas celestes, morada de las almas de los bienaventurados, cada vez más iluminadas hasta el Primer Motor. ${ }^{27}$ Esta visión del cosmos representó un «modelo aristotélico simplificado», en el cual la Tierra se hallaba quieta en el centro y los astros eran transportados por las esferas materiales cristalinas y transparentes; por encima, se encontraba la esfera de las estrellas y más allá, el Primer Motor. Así, Dante construyó un orden cosmológico, moral y estético a partir del ascenso por un cielo cada vez más bello, bueno y perfecto, donde se destacaban dos elementos claves: la luz y el sonido. El espacio medieval no era por lo tanto un espacio oscuro; el sol iluminaba la totalidad del universo y la noche sólo era posible por ser vista «a través del oscuro cristal de nuestra propia sombra». Tampoco el espacio medieval se hallaba en silencio por la creación de la armonía musical que produce el movimiento de las esferas. ${ }^{28}$ Una «vasta concavidad iluminada» y «resonante de música», tal era la visión medieval del cielo que encontró en La Divina Comedia su máxima expresión.

26. Lewis, Clive Staples: Op. cit., pp. 80-85.

27. Alıghieri, Dante: Divina Comedia. Barcelona, Altaya, 1980. Tomo XX: El Paraíso.

28. Gangul, Alejandro: Op. cit., pp. 73-81; Lewis, Clive Staples: Op. cit., pp. 90-92. 


\section{LA VISIÓN DEL CIELO EN LA APOCALÍPTICA CRISTIANA}

Relevada la dimensión hegemónica medieval de las representaciones celestes, nos proponemos resumir en este punto las características de uno de los múltiples repertorios de ideas en torno al cielo que ubicamos por fuera de la cristalización del discurso dominante. Particularmente aquellas que provienen de la tradición apocalíptica. En términos generales, el relato que propone el apocalipticismo refiere a situaciones o ideas que conllevan argumentos escatológicos: el fin del mundo como profecía teleológica hacia la destrucción del mundo físico. ${ }^{29}$ Esta tradición se constituyó a partir del conjunto de expresiones escritas surgidas en las tradiciones hebrea y cristiana desde los siglos Il y I AC hasta mediados del siglo II. Estos relatos expresaban por medio de símbolos y metáforas la situación de sufrimiento del pueblo judío o de los seguidores de Cristo y su esperanza en una intervención mesiánica salvadora o en la segunda venida de Cristo. Frecuentemente eran obras atribuidas a un personaje antiguo (patriarca, profeta, sabio, sacerdote) quien narraba una visión que recibió en vida. También eran relatos atribuidos a personajes que según la Biblia no han muerto (Enoc o Elías) o que han subido al cielo después de muerto (Isaías) o que han resucitado y trasmitían una revelación (Apocalipsis de San Juan). En todos los casos, se hallaba una profusión de imágenes y símbolos, con alusiones veladas a hechos históricos, que representaban conceptos generales, esperanzas y anuncios sobre el futuro. Ubicada entre la ortodoxia y la heterodoxia cristiana según el contexto histórico de su recepción, la creencia en la destrucción del mundo y en el juicio final formó parte de la doctrina oficial de la Iglesia desde sus orígenes. El Credo de Nicea, ratificado por el Primer Concilio de Constantinopla del año 38I, recogió la Segunda Venida de Cristo para juzgar a los vivos y muertos. Los textos apocalípticos incorporados en el canon de la Biblia son los libros de Daniel y de Isaías, los pasajes de Ezequiel, los libros de los profetas Zacarías y Joel, el discurso escatológico de los Evangelios del Nuevo Testamento, las cartas de San Pablo, el Apocalipsis de San Juan, el Libro de Henoc (en la iglesia etíope) y el de Esdras (en la Vulgata latina). ${ }^{30}$

A partir de estos relatos del fin del mundo, se forjó la creencia milenarista que tuvo capital importancia en la cultura europea occidental, como modalidad de la escatología cristiana, basada en la autoridad del Libro de la Revelación (20, 4-6), de que Cristo después de su Segunda Venida impondría un reino mesiánico sobre la tierra y establecería su reino por mil años antes del Juicio Final. ${ }^{\mathrm{I}}$ La tradición apocalíptica representaba una visión de esperanza, en medio de una situación

29. Sanmartín Barros, Israel: «Mesianismo, apocalipticismo y fin del mundo», Vegueta: Anuario de la Facultad de Geografía e Historia, 17 (2017), p. 9.

30. Rodríguez BARRAL, Paulino: La imagen de la justicia divina. La retribución del comportamiento humano en el más allá en el arte medieval de la Corona de Aragón. Barcelona, Universidad Autónoma de Barcelona, 2003, p. 18.

31. Corn, Norman: En pos del milenio. Revolucionarios milenaristas y anarquistas místicos de la Edad Media. Madrid, Alianza, 1981, p. 14. 
de opresión desproporcionada, en la cual afirmaba que no ha llegado el fin de la historia a pesar de la fortaleza del poder establecido. Por lo tanto respecto al presente, fue siempre crítica y pesimista, pero frente al futuro era optimista en cuanto que certificaba un cambio radical de la situación..$^{32}$

Resumidas las características generales de la tradición apocalíptica, nos preguntamos si las representaciones del cielo que en ellas se rastrean contradicen la proposición dominante de un cosmos medieval como objeto ordenado de forma sublime. En principio, en la escatología cristiana, la imagen del juicio final no presupone el fin del universo perfecto que se concibe sin pecado más allá de la Luna y, por lo tanto, las catástrofes que augura el relato escatológico se descargan sobre la tierra y no afectan a las regiones supralunares. Los cielos parecen quedar afuera de la anunciada catástrofe final. ${ }^{33}$ La visión cristiana del fin de los tiempos, por su carácter ambivalente propio del género apocalíptico, introdujo sin embargo elementos que perturbaban la imagen ordenada y armónica del cosmos medieval y que resultaron significativos en determinados contextos históricos de recepción. Para certificar esta ambivalencia, nos centramos en el relato por excelencia de la apocalíptica cristiana: el Apocalipsis de San Juan o Libro de la Revelación. El libro del Nuevo Testamento constituyó el legado más importante de la Antigüedad en términos de la difusión del ideario escatológico. Adoptando la forma simbólica de expresión, data de finales del siglo I o principios del Il, durante las cruentas persecuciones romanas contra los cristianos y conllevaba un trasfondo histórico con referencias múltiples a dichas persecuciones, exhortando a soportar las angustias y poniendo la esperanza final en la nueva Jerusalén. ${ }^{34}$ La palabra apocalipsis significa «descubierto», y de hecho, el conocimiento apocalíptico no postulaba más que una visión; «la revelación de Jesucristo, que Dios le dio, para manifestar a sus siervos las cosas que deben suceder pronto; y la declaró enviándola por medio de su ángel a su siervo Juan». ${ }^{5}$ Sobre esta revelación giró toda una discusión historiográfica que se resume en cuatro posiciones claves: la de aquellos que sostienen que se trataba de una obra de determinado tiempo pasado y que se explica en aquel tiempo; los que adoptaron un punto de vista historicista, según el cual el Apocalipsis constituye el relato del conjunto de la historia humana; la de quienes sostienen que es una visión del futuro; $y$, por último, los que afirmaron que la obra, por su alto contenido idealista, no refiere a hechos sino a principios generales..$^{36}$

En esta última perspectiva, podemos enmarcar el concepto de cielo que rastreamos en la obra. En principio, el vocablo que se repite sistemáticamente no

32. PAStORI RAmos, Aurelio: Las concepciones milenaristas en la Iglesia bajoimperial. Montevideo, Universidad de la República, 1987

33. LewIS, Clive Staples: Op. cit., pp. 96-98.

34. Prévost, Jean Pierre: Para leer el Apocalipsis. Madrid, Verbo Divino, 2001, pp. 27-32.

35. Apocalipsis de San Juan (1:1), en ReInA, Casiodoro y VARELA, Cipriano de: Op. cit., p. 1141.

36. CARO BAROJA, Julio: Las formas complejas de la vida religiosa. Religión, sociedad y carácter en la España de los siglos XVI y XVII. Madrid, Sarpe, 1985, pp. 263-264. 
refiere a la esfera celeste en tanto lugar físico sino que alude al más allá. Un concepto importado al judaísmo desde el zoroastrismo, quizás por el profeta Daniel debido a la exposición efectuada a los magos de la corte de Darío I. Transmitido al cristianismo y al Islam, el cielo supone un retorno al estado de la humanidad anterior a la caída, un segundo y renovado Jardín del Edén en el que la humanidad se reúne con Dios en un perfecto y natural estado de existencia eterna. Lugar de paz y felicidad infinita, el lugar del cielo representa lo inamovible, lo que siempre es estable, lo que es inmenso y grande; una realidad escatológica también designada como vida eterna o reino de Dios.

De igual manera, como la forma de expresión del texto es de carácter simbólico, tampoco se pueden considerar como parte de visiones celestes las referencias a estrellas y planetas que aluden en cambio a figuras no cosmológicas. Por ejemplo, destacamos la siguiente afirmación: «vi una estrella que cayó del cielo a la tierra; y se le dio la llave del abismo. Y abrió el pozo del abismo, y subió humo del pozo como humo de un gran horno; y se oscureció el sol y el aire por el humo del pozo».37 En esta cita, la estrella caída alude, indiscutiblemente, al demonio expulsado del paraíso y su descenso al infierno, acompañado luego en el inframundo por otros malos espíritus, quienes en el Apocalipsis aparecen también como estrellas caídas: «apareció otra señal en el cielo: he aquí un gran dragón escarlata..., y su cola arrastraba la tercera parte de las estrellas del cielo, y las arrojó sobre la tierra». ${ }^{38}$ Finalmente, afirma que «apareció en el cielo una gran señal: una mujer vestida del sol, con la luna debajo de sus pies, y sobre su cabeza una corona de doce estrellas», en alusión a la virgen como madre del universo. ${ }^{39}$ Estos y otros pasajes refieren a estrellas y planetas pero sólo como símbolos de otras fuerzas en la metáfora que el autor postuló.

Sin embargo, otras menciones del libro refieren a fenómenos celestes en sentido estricto y no como referencias al más allá, a ese lugar de inicio y destino de la humanidad y escenario del combate escatológico. Destacamos especialmente aquellos que aparecen en la teofanía de Dios y de la Nueva Jerusalén y los signos celestiales que preanuncian el fin de los tiempos. La teofanía de Dios, aparición visible a los seres humanos a través del relato de Juan, es la que nos introduce a la lectura del libro que, como todo relato teofánico, presentaba la escena con una profunda riqueza de detalles descriptivos. Se trata de la visión preliminar del trono de Dios. El autor la describe de la siguiente forma:

\footnotetext{
...he aquí una puerta abierta en el cielo; y la primera voz que oí, como de trompeta, hablando conmigo dijo: Sube acá, y yo te mostraré las cosas que sucederán después de estas... Y he aquí, un trono establecido en el cielo, y en el trono, uno sentado. Y el aspecto del que estaba sentado era semejante a piedra de jaspe y de cornalina; y había alrededor del trono un arco iris, semejante en aspecto a la esmeralda.
}

37. Apocalipsis de San Juan (9:1-2), en ReinA, Casiodoro y VARELA, Cipriano de: Op. cit., p. 1147.

38. Apocalipsis de San Juan (12:1), en ReINA, Casiodoro y VARELA, Cipriano de: Op. cit., p. 1149.

39. Apocalipsis de San Juan (12: 3-4), en ReInA, Casiodoro y VARELA, Cipriano de: Op. cit., p. 1149 
Con este pasaje se introduce una nueva sección que muestra al futuro desde la perspectiva del cielo. En esta visión, Dios se aparece sobre su trono, rodeado de seres vivientes y que le brindan adoración como creador. Para conjurar lo impredecible del futuro, el propósito del relato era mostrar que Dios está en el inicio en control de la historia humana y «habita en la luz inaccesible», por ello, la descripción se efectúa en términos de joyas preciosas. De la misma forma, se utiliza la semejanza al jaspe, para la presentación de la Nueva Jerusalén cuyo «resplandor era semejante a la piedra más preciosa, como piedra de jaspe, resplandeciente como cristal». Encontramos una visión de los cielos que se puede compatibilizar con esa región supralunar iluminada que caracterizó a la representación medieval, tanto en el origen como en el final del relato.

De igual forma otros relatos de la apocalíptica cristiana describieron fenómenos celestes en los tiempos postreros. La profética de Lactancio, por ejemplo, introduce estas imágenes en el siguiente pasaje:

Durante todo este tiempo las estrellas brillarán con mayor esplendor, y la luz del sol se incrementará, y la luna no se ocultará. Entonces las bendiciones de Dios descenderán como lluvia mañana y tarde, y la tierra producirá todos los frutos sin el trabajo del hombre. $4^{40}$

Este retórico pagano convertido al cristianismo y preceptor del hijo de Constantino auguraba para el milenio que «entonces el sol será siete veces más caliente que ahora». También Irineo, obispo de Lyon, quien falleció en el 208, señalaba que la Jerusalén renovada del milenio prepararía la Jerusalén definitiva del cielo «cuando la tierra haya sido renovada por el Señor y Jerusalén reconstruida a imagen de la Jerusalén celestial». El tópico apocalíptico se reiteró a través de los siglos, una nueva muestra de la continuidad cultural en la materia. Así el augurio apocalíptico de Campanella en el siglo XVI señalaba lo siguiente:

Habrá un nuevo cielo y una nueva tierra. El brillo del sol se multiplicará por siete y la luna será como el sol actual y esto durará mil años... En este tiempo las estrellas y los elementos serán purificados parcialmente y se verán imponer el orden y la disposición que convienen al siglo de oro, durante el cual los santos poseerán el mundo humano. ${ }^{41}$

Según la visión de Juan, en la Nueva Jerusalén, «no habrá allí más noche; y no tienen necesidad de luz de lámpara, ni de luz del sol, porque Dios el Señor los iluminará; y reinarán por los siglos de los siglos». Imagen simbólica del mal, la noche era abolida en el relato y la luz reinaba asociada a lo bueno.

Pero frente a la inmutabilidad celeste que santificaba el orden medieval, la visión de Juan concluye de hecho señalando que «vi un cielo nuevo y una tierra nueva; porque el primer cielo y la primera tierra pasaron, y el mar ya no existía más. Y yo Juan vi la santa ciudad, la nueva Jerusalén, descender del cielo, de Dios». Por lo tanto, la Nueva Jerusalén que desciende del cielo adquirió en el relato las características perfectas reservadas antes a la región supralunar, pero que en realidad era una nueva región. Juan introduce en su revelación la siguiente descripción: 
los cimientos del muro de la ciudad estaban adornados con todas piedras preciosas. El primer cimiento era jaspe; el segundo, zafiro; el tercero, ágata; el cuarto, esmeralda; el quinto, ónice; el sexto, cornalina; el séptimo, crisólito; el octavo, berilo; el noveno, topacio; el décimo, crisopraso; el undécimo, jacinto; el duodécimo, amatista. ${ }^{42}$

Este pasaje certifica que se trataba de un nuevo cielo ya que los signos del zodíaco tienen exactamente estas piedras asociadas, pero en el orden inverso. Encontramos aquí una primera disonancia con la visión del cosmos medieval: el surgimiento de un cielo y una tierra fulgurantes, perfectos y eternos habiendo logrado conjurar las amenazantes fuerzas del caos.

Como mensaje perturbador a la armonía del universo medieval, en el discurso apocalíptico adquirieren mayor importancia los signos anunciadores presentes en los septenarios de sellos, trompetas y copas. Los septenarios reconocen aproximadamente la misma estructura: una visión celeste como preludio de esperanza, una serie de cataclismos terrestres, luego del sexto símbolo hay un interludio de esperanza y finalizan con un triunfo total de salvación. Los sellos, trompetas y copas suponen una secuencia en la que las señales de la pronta destrucción se van intensificando hasta la llegada de Cristo en un clímax sobrecogedor. ${ }^{43}$ Muchas de estas señales aludían a fenómenos del mundo supralunar. Así, al abrir el sexto sello, Juan relataba la siguiente visión:

Hubo un gran terremoto; y el sol se puso negro como tela de cilicio, y la luna se volvió toda como sangre; $y$ las estrellas del cielo cayeron sobre la tierra, como la higuera deja caer sus higos cuando es sacudida por un fuerte viento. Y el cielo se desvaneció como un pergamino que se enrolla; y todo monte y toda isla se removió de su lugar. ${ }^{44}$

El sexto sello abría por tanto un período de desastres que afectaban a la tierra tanto como al cielo, similares a las señales del fin de la era, presentes también en el Evangelio de San Mateo (24: 29) cuando «los cuerpos celestes serán conmovidos». La apertura del séptimo sello en el Apocalipsis, cuando «se hizo silencio en el cielo como por media hora», como símbolo de un impasse de reflexión o porque el primer cielo y la primera tierra habían sido destruidos, daba comienzo al desarrollo de un nuevo simbolismo. Las siete trompetas anunciaban nuevas catástrofes: las primeras afectarán al universo físico (el sol, la luna, las estrellas) y las últimas a la humanidad, a un tercio de ella. Cabe señalar que la voz de Jesús sonaba como una trompeta en el inicio del relato para advertir sobre los desastres que se desencadenarán también en el mundo supralunar, cuando «fue herida la tercera parte del sol, y la tercera parte de la luna, y la tercera parte de las estrellas, para que se oscureciese la tercera parte de ellos, y no hubiese luz en la tercera parte del día, y asimismo de la noche». ${ }^{5}$

43. PrÉvost, Jean Pierre: Op. cit., p. 102.

45. Apocalipsis de San Juan (8: 1 y 12-13), en ReInA, Casiodoro y VARELA, Cipriano de: Op. cit., pp. 1146-1147. 
Las calamidades naturales que las trompetas preanunciaban acaban primero con la tierra y la vegetación, luego el mar, los ríos y las fuentes y finalmente el resto del universo será afectado, en la representación apocalíptica. La alusión constante a las plagas de los egipcios se infiere en el relato como forma de expresar que en los últimos días, Dios traerá de nuevo castigo sobre aquellos poderes opresores. Las siete copas aparecen similares y complementarias a las trompetas, pero pronosticaban el derramamiento final de la ira divina sobre toda la humanidad. Así, en el relato, Juan escucha una voz desde el templo que ordena «derramad sobre la tierra las siete copas de la ira de Dios» y entre ellas, destacamos cuando «el cuarto ángel derramó su copa sobre el sol y le fue dado el afligir a los hombres con ardor y fuego». Una vez más, la esfera de influencia de los ángeles se extiende hasta el sol y no sólo hasta la tierra en la pieza apocalíptica. El tópico de las calamidades se reiteró en las profecías medievales, particularmente en los pronósticos anónimos de I449 en tierras catalanas. En el relato, se señalaba que «el nacimiento del anticristo fue seguido por un eclipse del sol y de la luna... y la primera señal del fin del mundo fue que el sol perderá su claridad y la luna será como sangre». La profecía mencionaba entre las señales anunciadoras del fin que se quemará el cielo, la tierra y el mar hasta que emergen un nuevo cielo y una nueva tierra. ${ }^{6}$

El relato del Libro de la Revelación prosigue señalando que «entonces hubo relámpagos y voces y truenos, y un gran temblor de tierra, un terremoto tan grande, cual no lo hubo jamás desde que los hombres han estado sobre la tierra».47 Truenos, relámpagos y terremotos constituían otra de las formas de manifestación de la presencia de Dios en el Apocalipsis. Estos fenómenos se reiteraban constantemente en el relato y construyen una teofanía muy diferente a la visión del trono celestial o la Nueva Jerusalén por los sentimientos que generan. En el conjunto de calamidades que se pronosticaban, aquellas que provenían o afectaban al mundo supralunar adquirieron capital importancia porque comunicaban al lector un pathos de destrucción que ha permitido la vigencia cultural del género apocalíptico hasta los tiempos presentes. El oscurecimiento del sol y de la luna y la caída de las estrellas, junto a las leyendas relativas a los signos anunciadores del juicio final, conocieron una enorme difusión en la baja Edad Media e impregnaron el imaginario social en torno a la interpretación de los sucesos, cuando los fenómenos celestiales impredecibles e inexplicables fueron concebidos como las primeras señalesadvertencias del fin de los tiempos con fines como veremos muy diversos. ${ }^{48}$ Así el cosmos medieval postulado como perfecto y armonioso conforme a la representación hegemónica, se compatibiliza con aquel que rastreamos en el relato apocalíptico, aunque en este último perdió su carácter inmutable y sumó

46. AureLL, Martin: «La fin du monde, l'enfer et le roi: une prophétie catalans du XVe siécle», Revue_Mabillon, 5 , 66 (1994), pp. 143-177

47. Apocalipsis de San Juan (16:1, 8 y 17-19), en Reina, Casiodoro y VARela, Cipriano de: Op. cit., pp. 1151-1152.

48. Rodríguez Barral, Paulino: Op. cit., p. 11. 
señales atemorizantes que lo distanciaban de esa imagen luminosa que Dante le había conferido. La confrontación de los discursos y representaciones nos permiten entrever la presencia de disonancias; la importancia de las mismas sólo puede ser rastreada en los distintos contextos históricos de recepción, tarea que procuraremos efectuar a continuación.

\section{LA TRADICIÓN APOCALÍPTICA EN EL ORDEN MEDIEVAL}

Pensar la recepción de la disonancia apocalíptica nos obliga a pensar en un escenario dual dada la ruptura que significaron los tiempos bajomedievales en el pensamiento y en la praxis política. En cuanto a la recepción altomedieval, ya lejos del contexto de su producción, los distintos anuncios proféticos que integraban la tradición apocalíptica habían perdido autoridad canónica, cuando la iglesia oficializada asumió a partir del siglo IV su nueva situación de poder que se extiende y consolida a la caída del Imperio y precisó de nuevas representaciones ideológicas. Las ideas apocalípticas, desplazadas a un lugar marginal en la teología cristiana, mantuvieron cierta continuidad, a través de pronósticos en su mayoría anónimos, que fueron atribuidos a figuras indiscutidas del cristianismo. La corriente milenarista desapareció de la enseñanza oficial de la Iglesia desde fines del siglo $\mathrm{V}$, aunque continuaron circulando sus textos fundamentales, y mencionamos entre ellos al Libro de Daniel, las profecías de Ezequiel, el Apocalipsis de San Juan, el Apocalipsis de Baruc, la epístola del pseudo Bernabé, el Diálogo con Tifón de San Justino, los Oráculos sibilinos del siglo V y el tratado del Pseudo Metodio de fines del siglo VIl y comienzos del VIII. Con todo y pese a la circularidad sesgada de su ideario, la tradición sufrió una suerte de «eclipse» hasta su reaparición a principios del siglo XII. ${ }^{49}$

Los tiempos medievales parecen representar una ruptura significativa, ya que la visión del fin del mundo perdió los rasgos característicos que había conservado bajo el cristianismo primitivo y su continuidad en la patrística. A finales del siglo IV y principios del siglo $\mathrm{V}$ había surgido una poderosa reacción contra el apocalipticismo en Occidente gracias a la acción de Agustín de Hipona, quien contribuyó a situar al milenarismo al margen de la ortodoxia..$^{\circ}$ En términos agustinianos, el relato escatológico se componía de siete edades, análogas a los siete días de la creación, que culminaban en una edad del Sabbath. Pero San Agustín había colocado esta séptima edad fuera del proceso temporal, afirmando que el

49. Rucquol, Adeline: «Mesianismo y milenarismo en la España medieval», Medievalismo. Revista de la Sociedad Española de Estudios Medievales, Nº, Madrid, 1996, pp. 9-31.

50. Romero Pérez, Antonio: «Milenarismo, utopía e ideología», Vegueta: Anuario de la_Facultad de Geografía e Historia, 17 (2017), p. 201. 
clímax de la historia ya había ocurrido con la Encarnación y que lo restante del proceso del tiempo era simplemente un período de arrepentimiento, vivido a la sombra del juicio. ${ }^{\text {II }}$ En su obra, se oponía a toda interpretación literal de las promesas bíblicas acerca del reino mesiánico y a la inminencia profética atacando los fundamentos teológicos del apocalipticismo. San Agustín no rechazaba la enseñanza bíblica acerca de los hechos del fin de los tiempos, pero insistía que las predicciones apocalípticas no ofrecían las claves del significado de los hechos contemporáneos y rechazó todo intento de determinar la época del fin. Es más Agustín hizo inmanente la escatología al introducir en el alma el significado de la historia: las edades del mundo y su objetivo son el modelo para el verdadero significado de la historia, el desarrollo moral del creyente..$^{52}$

El ataque de san Agustín contra el milenarismo tuvo enorme influencia durante toda la alta Edad Media y nadie rechazó sus argumentos hasta el siglo XII. El temprano pensamiento medieval llevó la impronta del agustinismo. ${ }^{53}$ Los historiadores han señalado la ausencia casi total del relato apocalíptico en la Alta Edad Media pese a su supervivencia en manifestaciones de religiosidad popular o en determinadas elaboraciones tales como en los Comentarios del Beato de Liébana o en la obra de Gonzalo de Berceo en tierras hispánicas. ${ }^{54}$ Richard Landes ha puesto de manifiesto la existencia de un milenarismo altomedieval reprimido por la doctrina oficial, pero que se multiplicó en manifestaciones diversas y permanentes, relativizando la influencia agustiniana y afirmando la continuidad cultural de los tópicos del fin de los tiempos como denominador común de las enseñanzas bíblicas y como recurso habitual de la predicación para la conversión de los infieles.55 Lo cierto es que aún a comienzos del siglo XIII, las expectativas del futuro se edificaban sobre un relato escatológico ortodoxo, que sin abandonar la esperanza apocalíptica, la neutralizaba e integraba en la visión armoniosa del universo medieval. La claridad y naturaleza abstracta del pensamiento de Santo Tomás de Aquino en asuntos celestiales se convirtió en estándar dentro de la teología católica, pero la riqueza emocional de las visiones del más allá en el fin de los tiempos continuaba siendo la encargada de robustecer las sucesivas generaciones de especulaciones acerca del Cielo..$^{56}$ En contextos sociohistóricos críticos como lo veremos a continuación, esta actividad especulativa plasmó nuevas representaciones y la circularidad de ideas apocalípticas terminó por conmover no sólo la visión hegemónica del cielo sino también por amenazar al status quo dominante.

51. ReEves, Marjorie: «Pauta y propósito en la historia: los períodos de la Baja Edad Media y el Renacimiento», en BuLL, Malcolm (comp.) Op. cit., p. 109.

52. San Agustín: La ciudad de Dios (antología filosófica). Buenos Aires, Hyspamerica, 1985, cc. 20-30.

53. McGINN, Bernard: «El fin del mundo y el comienzo de la cristiandad», en BuLL, Malcolm (comp.): Op. cit., pp. 80-96.

54. RucQuol, Adeline: «Medida y fin de los tiempos. Mesianismo y milenarismo en la Edad Media», en En pos del tercer milenio: apocalíptica, mesianismo, milenarismo e historia. Salamanca, Universidad de Salamanca, 2000, pp. 13-41.

55. LANDES, Richard: Heaven on Earth: The varieties of the millenial experience. Oxford, Oxford University Press, 2011.

56. Santo Tomás: Summa Teologiae: Prima Pars. Madrid, Biblioteca de Autores Cristianos, 1994 


\section{LA RELECTURA CRÍTICA BAJOMEDIEVAL Y EL CIELO APOCALIIPTICO}

La relectura de los pasajes del «Libro de la Revelación» y otros relatos escatológicos en el contexto bajomedieval por Joaquín de Fiore y sus sucesores provocaron un quiebre definitivo con la visión ortodoxa celestial con amplias repercusiones políticas que trascendieron su tiempo. El abad y ermitaño calabrés del siglo XII intentó descubrir el significado oculto de las Escrituras. Formuló una interpretación alegórica de la Biblia, que describe el proceso de la historia en tres edades sucesivas. La primera edad es la del Padre, la de la ley; la segunda corresponde al Hijo, el Evangelio; y la tercera es la del Espíritu, la luz. El temor y la servidumbre que padecen en la primera los cristianos darán paso a la fe y sumisión en la segunda etapa y finalmente al amor, alegría y libertad de la tercera en la cual el mundo aparecerá compuesto sólo por monjes en estado de contemplación, nueva versión del reino de los santos hasta el juicio final. Cada una de estas edades conocerá, según el abad, un período de incubación de cuarenta y dos generaciones. Así, la primera estuvo precedida por el período que va de Adán a Abraham, la segunda por el transitado entre Elías y Cristo, y finalmente, de San Benito al siglo XII transcurrió el período que precede a la tercera etapa. La tarea preparatoria la depositó Dios supuestamente en una nueva orden de monjes de doce patriarcas y un maestro supremo; tres años y medio antes del Anticristo surgiría un rey secular que castigaría a la Iglesia mundana, para que a su muerte reinara el Espíritu. ${ }^{57}$ Esta doctrina no fue considerada herética en su tiempo, aunque resultó irreconciliable con el agustinismo dogmático de la Iglesia medieval por dos motivos: la aseveración de la inminencia y cálculo del fin de los tiempos y el postulado de esta tercera edad o milenio de abundancia a partir de la acción humana.

La interpretación joaquinita permitió la recuperación de una inminencia profética presente ya en el «Apocalipsis de San Juan», dado que al comienzo del escrito, leemos: «bienaventurado el que lee, y los que oyen las palabras de esta profecía, y guardan las cosas en ella escritas; porque el tiempo está cerca». En los pasajes finales del libro, se repite varias veces este anuncio de la cercanía del tiempo de la parusía. «jHe aquí, vengo pronto!», exclama Dios, según el relato, antes de proferir su bendición, y más adelante exhorta a atesorar estas palabras, con el siguiente comentario:

... porque el tiempo está cerca. El que es injusto, sea injusto todavía; y el que es inmundo, sea inmundo todavía; y el que es justo, practique la justicia todavía; y el que es santo, santifíquese todavía. He aquí yo vengo pronto, y mi galardón conmigo, para recompensar a cada uno según sea su obra.

57. Corn, Norman: Op. cit., pp. 107-110. 
Finalmente reafirma «ciertamente vengo pronto. Amén, así sea. Ven, Señor Jesús», concluyendo el relato..$^{8}$ La reactualización del tópico sobre la proximidad del final de los tiempos confirió al género apocalíptico un nuevo papel en el universo ideológico bajomedieval. El joaquinismo provocó un giro en la apocalíptica cristiana al colocar en el presente su tiempo de consumación. En los escritos del siglo XIIl, se repite frecuentemente la expresión «en estos últimos días», señalando el general sentido de crisis de una época que se sentía en el umbral del fin de los tiempos a partir de los augurios del visionario calabrés ${ }^{59} \mathrm{y}$ también por la vivencia crítica de los años de contracción bajomedievales.

Además, si bien la fecha en la que se suponía debían cumplirse los oráculos y profecías escatológicas es siempre una fecha indeterminada e imprecisa, el joaquinismo y las corrientes proféticas a las que dio origen intentaron determinar con precisión su emergencia en el futuro inmediato. En ese intento, apelaron al concurso de la Astrología, corriente de pensamiento de la Antigüedad heredada por la Edad Media, que parte del principio que los fenómenos astrales ejercen una influencia determinada sobre la naturaleza. La astrología se presentó históricamente como el arte de la correspondencia terrestre y celestial. ${ }^{60}$ Ciencia de los influjos estelares sobre la vida en la tierra, la astrología derivaba efectos físicos a partir del nombre de las estrellas, según los mitos que le atribuían propiedades a estas deidades antiguas. ${ }^{61}$ La visión astrológica unía el dios antiguo, la fuente de influencia sobre la tierra y el planeta visible en el cielo. De esta unidad, la Iglesia no podía aceptar la derivación de cualquier tipo de determinismo astrológico, porque negaba el libre albedrío. Por ello, el advenimiento del cristianismo oficial no sólo trajo consecuencias para la continuidad del repertorio apocalíptico sino que también supuso el derrumbe y eclipse de la astrología hasta el siglo XII. San Agustín en «La Ciudad de Dios» cuestionaba el principio de la determinación por las estrellas; el fundamento explicativo de la historia se encuentra en la providencia divina y no en la astrología, ya que el movimiento de los astros depende de la voluntad de Dios. El libre albedrío de los hombres y la providencia divina, señalaba, determinan los acontecimientos. ${ }^{62}$ Hasta la irrupción de la revolución científica moderna, constituyó la visión hegemónica. A partir de Copérnico y sobre todo con Galileo, se amplían las dimensiones del cosmos y se desaloja de su centro a la Tierra, afirmando la centralidad del sol. Surge el concepto de universo como mundo unificado, donde impera la universalidad de las leyes de la física y las reglas matemáticas sobre el cielo y la tierra; proceso que completa la teoría newtoniana sobre la mecánica

58. Apocalipsis de San Juan (1:3, 22:7, 10-12 y 20), en ReINA, Casiodoro y VARELA, Cipriano de: Op. cit., pp. 1141 y 1157.

59. Reeves, Marjorie: Op. cit., pp. 109-114.

6o. AURELL, Martín: «Eschatologie, spiritualité et politique dans la Confederation Catalano-Aragonaise (1282-1412)», Cahiers de Fanjeaux, 27, 1992, pp. 191-235.

61. Warburg, Aby: Op. cit., pp. 416-417.

62. San Agustin: Op. cit., libro V, cc.1-7. 
celeste y sus interacciones gravitacionales. ${ }^{63}$ La revolución astronómica asesta el golpe final contra la astrología que reapareció en el contexto europeo hacia finales del siglo XII, con la puesta en circulación a partir de las traducciones toledanas de los textos antiguos.

Antes de su eclipse definitivo y en aquel contexto de reactualización, la astrología aportó elementos esenciales a la apocalíptica posjoaquinita. El texto clave contra toda especulación astrológica fue la orden de Cristo: «a vosotros no os toca conocer el tiempo y el momento en que ha fijado el Padre con su autoridad». ${ }^{64}$ Quien se atrevió a desafiar esta premisa imperante del orden medieval fue el visionario Arnau de Vilanova, quien puso al día la pauta joaquinita de la historia, profetizando inmediatas y violentas tribulaciones políticas y múltiples anticristos. ${ }^{65}$ Pronosticaba que las autoridades existentes, seculares o eclesiásticas, serían derrotadas y se llegaría al período de la bienaventuranza que se expresa como la más alta pobreza evangélica. ${ }^{66}$ Pese a este radicalismo profético, el debate académico giró sobre lo legítimo de tratar de predecir los acontecimientos del fin de los tiempos. Dos aportes esenciales de la Astrología tendrán capital importancia para el desarrollo de la apocalíptica bajomedieval: los «vaticinia» y la doctrina de las conjunciones planetarias. Es que en la adivinación astrológica se fusionaba el pensamiento abstracto matemático, que calcula anticipadamente sucesos por la posición de las estrellas fijas entre ellas y respecto a la Tierra y la causalidad religiosa. Los planetas convertidos en «regentes del mundo y divinidades del momento concreto», al ser observados en cooperación, cuando se hallan en conjunción, tras largos períodos de tiempo anuncian efectos decisivos sobre la tierra. ${ }^{67}$ Pero si el cálculo astrológico del fin de los tiempos fue el eje de las discusiones eruditas bajomedievales, en los círculos de gente devota el debate se centró sobre los papeles a cumplir en el último drama.

La contribución posbíblica más destacable respecto al milenarismo la realizó también Joaquín de Fiore, quien dotó a la apocalíptica cristiana de un elemento central: la agencia. Es que ese milenio prometido y próximo debía ser construido y no esperado. La nueva perspectiva joaquinita, a partir de su pauta trinitaria, otorgó propósito al proceso temporal en un desplazamiento progresivo hacia un nuevo clímax espiritual dentro de la historia. Una expectativa más positiva que la agustiniana que reservaba un papel crucial en la última edad a ciertas agencias humanas, convicción que avivó las mentes imaginativas y formó un eficaz contrapeso a las expectativas negativas de intervención sobrenatural directa para el fin de los tiempos. Joaquín de Fiore supeditó a la acción humana el ambivalente fin de los tiempos. El tema echó raíces en nuevas órdenes religiosas,

63. Gangui, Alejandro: Op. cit., pp. 110-125.

64. Hechos de los Apóstoles (1:7), en Reina, Casiodoro y Varela, Cipriano de: Op. cit., p. 1002.

65. Vilanova, Arnau: «Tractatus de tempore adventus Antichrist», Arxiu de textos catalans antic, 7/8 (1998), pp. 7-169.

66. ReEVES, Marjorie: Op. cit., pp. 115-116.

67. Warburg, Aby: Op. cit., pp. $448-467$ 
cuyos miembros se creyeron llamados a una vocación especial en la última edad. Adoptaron formas ortodoxas de renovación de la vida apostólica, cumpliendo la profecía evangélica de conversión antes del fin de los tiempos. Con la conmoción de la cristiandad ante el traslado de la sede papal a Aviñón de I309 a I376 y el consecuente cisma de Occidente de $\mathrm{I}_{377}$ a I4I5, la corriente profética apocalíptica joaquinita dio origen a una multitud de grupos heterodoxos. Un arsenal inagotable de inquietudes apocalípticas conectó con las preocupaciones fundamentales de la sociedad bajomedieval y dio cuerpo a la actividad de reformadores ortodoxos y heterodoxos y a movimientos antijerárquicos. ${ }^{68}$ La cristiandad asistía entonces al empuje de la tendencia a la «reformatio» de la vida misma para el advenimiento de una edad más pura inspirada en la idea del Evangelio Eterno que instalaría el reino de Dios entre los hombres. Se postuló la visión de una sociedad sin diferencias sociales por renuncia a los bienes materiales y esta fantasía no pudo dejar de tener un profundo significado ante la opulencia y laxitud moral que caracterizaba a la Iglesia, castigada por sus pecados con el cisma. Las ideas joaquinitas fueron soporte de la acción de espirituales convertidos en la personificación de la nueva orden prevista e influenciaron a personajes muy diversos como Cola di Rienzo y los fraticellis, Vilanova, Dante, Rocatallada, Ferrer, Bernardino de Siena, Savonarola y Colón. En grupos abiertamente heterodoxos, las ideas joaquinitas se rastreaban en los flagelantes, los hermanos apostólicos de Gerardo Segarelli y Dolcino de Novara, en los hermanos del libre espíritu y pueden establecerse contactos de la escatología Joaquinita con los grupos de lollardos ingleses seguidores de Wyclif, el husismo y las agitaciones sociales de I38I, I4I4 y I43I. ${ }^{69}$ El joaquinismo resultó irreconciliable con el agustinismo dogmático de la Iglesia medieval y su doctrina funcionará como sustrato de la acción colectiva por varios siglos..$^{\circ}$

$\mathrm{Al}$ igual que en la tierra, las representaciones celestiales adquirieron movimiento y actividad y delinearon un nuevo imaginario colectivo. El cielo medieval fue descripto como una estructura cónica en cuyo anillo más elevado y próximo se hallaba la morada de Dios. La rigidez, inmutabilidad y jerarquización del cielo medieval comenzaba a desaparecer de los relatos desde los tiempos bajomedievales. Si Santo Tomás señalaba que la vida activa humana acaba con la muerte y por tanto, en el más allá solo habrá contemplación, la observación astronómica descubrió movimiento en los astros, dando inicio a un camino que culminará con la revolución científica de la modernidad. Pero también la teología renacentista le atribuyó actividad a la existencia humana en el más allá, como en De la contemplación (I:I8) de Dionisio el cartujo. Se plasmó la visión de una vida activa en el cielo, libre

68. Álvarez Palenzuela, Vicente: «Milenarismos y milenaristas en la Edad Media: una perspectiva general», en Milenarismos y milenaristas en la Europa Medieval. IX Semana de Estudios Medievales. Najera, Institutos de Estudios Riojanos, 1998, p. 26

69. Álvarez Palenzuela: Op. cit., pp. 27-31.

70. ReEves, Marjorie: Op. cit., pp. 109-114. 
de toda imperfección, y el movimiento fue señalado como aquel que construye precisamente la existencia paradisíaca. ${ }^{7 \mathrm{I}}$ La pérdida de la inmovilidad en la tierra como en el cielo no sólo creó nuevas visiones sobre el más allá sino que también contribuyó a la gestación de nuevas formas de pensar la sociedad en el contexto crítico de la primera crisis del sistema feudal.

A partir de los tiempos bajomedievales, la apocalíptica cristiana se transformó en herramienta privilegiada de control social y político. A través del relato escatológico y particularmente empleando, tanto en la propaganda oficial como en los sermones, las imágenes de los signos anunciadores, se impuso el mando y se reforzó la obediencia, transformándose tanto en un arma para la moralización del creyente o la conversión del infiel como para extender la dominación imperial o real. ${ }^{72}$ En los siglos XIV, XV y XVI las esperanzas escatológicas no se depositaban tanto en la vuelta de Cristo como artífice del reino de mil años sino en la aparición de un rey providencial que uniría a los cristianos bajo su mando, lograría la conversión de los infieles previo a su traslado a Jerusalén. En la península ibérica, esta figura, la del emperador de los últimos tiempos, se asoció históricamente a los reyes de la Corona de Aragón y a Fernando el católico y se halla presente también en las «Trovas de Bandarra» de 1530 que preanunciaban un último emperador portugués.73 Entre los múltiples tratados escritos al servicio de los imperios, referimos el caso de Juan de Rocatallada, quien preanunció la emergencia de un fraile franciscano como «papa angélico» que se convertiría en líder de la Iglesia y que ayudaría al rey de Francia, el último emperador, para ser elegido como Sacro Emperador Romano. Tras la derrota del Anticristo, ambas figuras escatológicas contribuirían, según Rocatallada, a la reconstrucción del mundo y el milenio seguiría hasta el fin de los tiempos. ${ }^{74}$

Las ideas escatológicas cumplieron también históricamente otros usos dado que se transformaron en instrumento crítico hacia las jerarquías dominantes y en sustrato cultural de diversos y continuos levantamientos, conflictos, revueltas y revoluciones hasta el siglo XVII en la Europa Occidental. La prédica apocalíptica constituyó así un elemento clave del repertorio cultural de los poderosos, pero también confirió protagonismo y dignidad a los desheredados de las sociedades del Antiguo Régimen. ${ }^{75}$ El apocalipcismo en tiempos bajomedievales y modernos alimentó el ideario de grupos socialmente sometidos, económicamente deprimidos y socialmente marginados y excluidos. Entre las innumerables profecías,

71. DıONISIO: Opera omnia. Tournai, Carthusia, 1912, XLI, p. 154

72. Guadalajara Medina, José: «Preocupaciones apocalípticas en la Europa Medieval», en: Milenarismos y milenaristas en la Europa medieval. IX Semana de Estudios Medievales. Nájera, Ayuntamiento. 1999, pp. 257-280.

73. Rucquol, Adeline: «Mesianismo...» Op. cit., pp. 30-31

74. DE VUn, Leah: Prophesy, Alchemy and the End of Times: John of Rupescissa in the Late Middle Ages. New York, Columbia University Press, 2009, pp. 36-37.

75. Moreno Vaquerizo, Antonio: «Milenarismo y Comunidades de Castilla: propósito del liderazgo mesiánico de los caudillos comuneros», Política y cultura en la época moderna (cambios dinásticos, milenarismos, mesianismos y utopías). Madrid, Fundación Española de Historia Moderna, 2004, pp. 553-564. 
mayoritariamente anónimas, que legitimaron la acción colectiva en dicho contexto sociohistórico, destacamos el caso de la obra «De la venguda de Antichrist» de Joan Alamany y su instrumentalización en la revuelta agermanada (I5I9-I522). Los postulados subversivos de la obra auguraban el triunfo de la violencia de los pobres contra los moros, los privilegiados y los malos gobiernos a partir de la llegada de un rey Encubierto, «entonces los pobres desollados vencerán a los lobos hambrientos y a todos sus ayudadores... juntarse han con los del Encubierto y limpiarán la gran ciudad y toda su tierra». ${ }^{76}$ La instrumentalización apocalíptica por parte de los rebeldes la convirtió en arma de guerra y soporte ideológico de su lucha social y política durante el conflicto. En el mismo se producirá la personificación de esta figura, por primera vez un «contramonarca escatológico» plebeyo, quien asumió el programa del monarca de los últimos tiempos y que «había venido al mundo para oprimir a los tiranos y remediar a los pueblos». ${ }^{77} \mathrm{La}$ apocalíptica se transfiguró en expectativa de cambio social posible con el Encubierto plebeyo y los sucesivos encubiertos que tomaron a su muerte el relevo revolucionario, transformándose en forma eficaz de subversión que trascendió el tiempo histórico de la Germanía. ${ }^{78}$ Estos múltiples usos de la apocalíptica, como acicate en favor del orden institucional vigente o como soporte de la lucha social, encuentran explicación a partir de la centralidad que en toda la etapa tuvo la escatología en el pensamiento religioso. Tomando este rango amplio de pensamiento, podemos concebir una enorme extensión del fenómeno ideológico dado que operó como ítem de la propaganda visual, tópico de disputa en sermones, panfletos y tratados y como lo reflejó este artículo, en sujeto de especulaciones astronómicas y astrológicas. De tal forma, compartir este ideario era una indicación del profundo involucramiento en la mentalidad colectiva de una era donde la brujería y el demonismo adoptaron un carácter omnipresente. ${ }^{79}$

\section{A MODO DE CONCLUSIÓN}

Al resumir el recorrido trazado, desde el contexto de su producción al contexto de circulación de las ideas celestes, podemos concluir que las disonancias que parecían introducir la apocalíptica cristiana a través de sus textos fundantes

76. Alamany, Joan: «De la venguda de Antichrist e de les coses que se han de seguir, ab una reprobació de la secta mahomètica», en Durán, Eulàlia y Requesens, Joan. Profecia i poder al Renaixement. Texts profètics catalans favorables a Ferran el Catòlic. Valencia, Edicions 3i4, 1997, pp. 73-133.

77. Como síntesis del conflicto agermanado destacamos a TEROL I REIG, Vicent: «Contra cavallers i en defensa del Reial Patrimoni. Temps de Germania», en Carolus Rex Valentiae. Els valencians i l'imperi. Valencia, Biblioteca Valenciana, 2000 , pp. 50-85.

78. DURÁN, Eulàlia; «Aspectes milenaristes en les germanies valencianes», El contemporani: revista d'història, 5 , 1995, pp. 21-29.

79. CLARK, Stuart: Thinking with Demons: The Idea of Witchcraft in Early Modern Europe. Oxford, Clarendon Press, 1997, pp. 321-345. 
respecto a la visión medieval de los cielos, no pueden concebirse como una ruptura significativa con las representaciones hegemónicas. La afirmación de un nuevo cielo escatológico y los temores que generaban los preanuncios celestiales perturbaron, sin embargo, la visión ordenada del cosmos reflejada por Dante. Estos desplazamientos de sentido alimentaron las especulaciones astronómicas y teológicas en torno a las representaciones celestiales hasta dar paso a una ruptura manifiesta en el contexto de reactualización bajomedieval de las ideas apocalípticas que otorgó una perspectiva diferente a la acción humana. Es que el apocalipticismo cristiano en este contexto no enfocó exclusivamente el final de los tiempos sino también «el presente como oportunidad decisiva para la transformación del mundo», otorgándole un carácter crítico. Ese presente apareció como un momento de enorme significación dentro de la historia, que no podía contemplarse con desapego y exigía un compromiso que obligaba a la acción. Por esta recuperación, el joaquinismo produjo una escatología que ejercería una profunda influencia sobre el pensamiento europeo y el imaginario colectivo durante los siglos venideros, que unió la escatología con el cambio político. A partir de esta transformación cultural, la mirada astronómica permitió afirmar que el cielo, como el mundo, tenía un fin, concebido tanto como término (su final) y como «telos» (una finalidad) que debía alcanzar la condición humana con su praxis. ${ }^{80}$ Lejos de la mirada contemplativa medieval de un universo ordenado y perfecto, las visiones celestes en movimiento de una tradición apocalíptica, reactualizada con los caracteres centrales de la inminencia y la agencia, anticiparon, reflejaron y acompañaron la transición a los convulsos tiempos modernos.

80. RowLAND, Christopher: «Los que hemos llegado a los fines de los tiempos: lo apocalíptico y la interpretación del Nuevo Testamento», en BuLL, Malcolm (comp.): Op. cit., pp. 56-57. 


\section{BIBLIOGRAFÍA}

Alamany, Joan: De la venguda de Antichrist e de les coses que se han de seguir, ab una reprobació de la secta mahomètica, en Durán, Eulàlia y Requesens, Joan. Profecia i poder al Renaixement. Texts profètics catalans favorables a Ferran el Catòlic. Valencia, Edicions 3i4, I997, pp. 73-133.

Alighieri, Dante: Divina Comedia. Barcelona, Altaya, I980.

Álvarez Palenzuela, Vicente: «Milenarismos y milenaristas en la Edad Media: una perspectiva general», en Milenarismos y milenaristas en la Europa Medieval. IX Semana de Estudios Medievales. Najera, Institutos de Estudios Riojanos, I998, pp. II-32.

Aristóteles: Acerca del cielo. Madrid, Gredos, I996.

Aurell, Martin: «La fin du monde, l'enfer et le roi: une prophétie catalane du XVe siécle», Revue Mabillon, 5, 66 (1994), pp. I43-I77.

Aurell, Martín: «Eschatologie, spiritualité et politique dans la Confederation CatalanoAragonaise (I282-I4I2)», Cahiers de Fanjeaux, 27, I992, pp. I9I-235.

BACzKo, Bronislaw: Los imaginarios sociales. Memorias y esperanzas colectivas. Buenos Aires, Nueva Visión, I99I.

Benigno, Francesco: Espejos de la revolución. Conflicto e identidad política en la Europa moderna. Barcelona, Crítica, 2000.

Bourdieu, Pierre: El sentido práctico. Madrid, Taurus, I99I.

Bourdieu, Pierre: La distinción: criterios y bases sociales del gusto. Madrid, Taurus, I999.

Bull, Malcolm (comp.): La teoría del apocalipsis y los fines del mundo. México, FCE, 1998.

Burke, Peter (ed.): Formas de hacer historia. Madrid, Alianza, I994.

CARO BAROJA, Julio: Las formas complejas de la vida religiosa. Religión, sociedad y carácter en la España de los siglos XVI y XVII. Madrid, Sarpe, I985.

Chartier, Roger: El mundo como representación. Historia cultural: entre práctica y representación. Barcelona, Gedisa, I995.

ChARTIER, Roger: Escribir las prácticas. Foucault, de Certeau, Marin. Buenos Aires, Manantial, 1996.

Cicerón, Marco Tulio: El sueño de Escipión. Barcelona, Acantilado, 2004.

CLARK, Stuart: Thinking with Demons: The Idea of Witchcraft in Early Modern Europe. Oxford, Clarendon Press, I997.

CoHn, Norman: En pos del milenio. Revolucionarios milenaristas y anarquistas místicos de la Edad Media. Madrid, Alianza, I98I.

De la IgLESIA DUARTE, José Ignacio (coord.) Milenarismos y milenaristas en la Europa Medieval. IX Semana de Estudios Medievales. Najera, Instituto de Estudios Riojanos, I998.

DelumeaU, Jean: «Historia del milenarismo en Occidente», Historia crítica, 23 (2003), pp. 7-20.

DE VUn, Leah: Prophesy, Alchemy and the End of Times: John of Rupescissa in the Late Middle Ages. New York, Columbia University Press, 2009.

Dionisıo: Opera omnia. Tournai, Carthusia, I9I2.

DurÁN, Eulàlia; «Aspectes milenaristes en les germanies valencianes», El contemporani: revista d'història, 5, I995, pp. 2I-29.

Gangui, Alejandro: El Big Bang. La génesis de nuestra cosmología actual. Buenos Aires, Eudeba, 2005.

GinZburG, Carlo: El queso y los gusanos. El cosmos según un molinero del siglo XVI. Barcelona, Muchnik, I98I. 
Guadalajara Medina, José: «Preocupaciones apocalípticas en la Europa Medieval», en Milenarismos y milenaristas en la Europa medieval. IX Semana de Estudios Medievales. Nájera, Ayuntamiento, I999, pp. 257-280.

LAClAU, Ernesto y MOUfFe, Chatal: Hegemonía y estrategia socialista. Hacia una radicalización de la democracia. Buenos Aires, FCE, 2004

LANDES, Richard: Heaven on Earth: The varieties of the millenial experience. Oxford, Oxford University Press, 2011.

LEwIs, Clive Staples: La imagen del mundo: Introducción a la literatura medieval y renacentista. Barcelona, Península, I997

MAcrobio: Comentario al sueño de Escipión. Madrid, Siruela, 2005

McDAnnell, Collen y LANG, Bernhard: Historia del cielo. Madrid, Taurus, 20oI

McGinN, Bernard: «El fin del mundo y el comienzo de la cristiandad», en BuLl, Malcolm (comp.): La teoría del apocalipsis y los fines del mundo. México, FCE, I998, pp. 75-108.

Moreno Vaquerizo, Antonio: «Milenarismo y Comunidades de Castilla: propósito del liderazgo mesiánico de los caudillos comuneros», Política y cultura en la época moderna (cambios dinásticos, milenarismos, mesianismos y utopías). Madrid, Fundación Española de Historia Moderna, 2004, pp. 553-564.

PARMA, Mariana: Guerras plebeyas. Lucha política en las revueltas de la temprana modernidad: aspectos teóricos, estudio del caso agermanado y análisis comparativo. (Tesis doctoral inédita). Universidad de Buenos Aires, 2017

PASTORi RAmos, Aurelio: Las concepciones milenaristas en la Iglesia bajoimperial. Montevideo, Universidad de la República, I987

Platón: Timeo. Buenos Aires, Colihue, 2005

PrÉvost, Jean Pierre: Para leer el Apocalipsis. Madrid, Verbo Divino, 200 I

ReEves, Marjorie: «Pauta y propósito en la historia: los períodos de la Baja Edad Media y el Renacimiento», en BULL, Malcolm (comp.): La teoría del apocalipsis y los fines del mundo. México, FCE, I998, pp. I09-I32.

Reina, Casiodoro y Varela, Cipriano de: La Santa Biblia: Antiguo y Nuevo Testamento. Buenos Aires, Sociedades Bíblicas en América Latina, I960

Rocatallada, Joan de. «Vade mecun in tribulatione», Arxiu de textos catalans antics, I2, Barcelona I993, pp. 75-I40.

Rodríguez BARRAL, Paulino: La imagen de la justicia divina. La retribución del comportamiento humano en el más allá en el arte medieval de la Corona de Aragón. Barcelona, Universidad Autónoma de Barcelona, 2003

Romero Pérez, Antonio: «Milenarismo, utopía e ideología», Vegueta: Anuario de la_Facultad de Geografía e Historia, I7 (2017), pp. I99-2II

Rowland, Christopher: «Los que hemos llegado a los fines de los tiempos: lo apocalíptico y la interpretación del Nuevo Testamento», en BULL, Malcolm (comp.): La teoría del apocalipsis y los fines del mundo. México, FCE, I998, pp. 5I-74.

Rucquol, Adeline: «Medida y fin de los tiempos. Mesianismo y milenarismo en la Edad Media», en En pos del tercer milenio: apocalíptica, mesianismo, milenarismo e historia. Salamanca, Universidad de Salamanca, 2000, pp. I3-4I.

RucQuol, Adeline: «Mesianismo y milenarismo en la España medieval», Medievalismo. Revista de la Sociedad Española de Estudios Medievales, N 6, Madrid, I996, pp. 9-3I.

SAn Agustín: La ciudad de Dios (antología filosófica). Buenos Aires, Hyspamerica, I985

Sanmartín Barros, Israel: «Mesianismo, apocalipticismo y fin del mundo», Vegueta: Anuario de la Facultad de Geografía e Historia, I7 (2017), pp. 9-23.

Santo tomás: Summa Teologiae: Prima Pars. Madrid, Biblioteca de Autores Cristianos, 1994 
Terol i Reig, Vicent: «Contra cavallers i en defensa del Reial Patrimoni. Temps de Germania», en Carolus Rex Valentiae. Els valencians i l'imperi. Valencia, Biblioteca Valenciana, 2000, pp. 50-85.

VACA LORENZO, Ángel (coord.) En pos del tercer milenio: apocalíptica, mesianismo, milenarismo e historia. Salamanca, Universidad de Salamanca, 2000.

Vilanova, Arnau: «Tractatus de tempore adventus Antichrist», Arxiu de textos catalans antic, 7/8 (1998), pp. 7-I69.

WARburg, Aby: El renacimiento del paganismo. Aportaciones a la historia cultural del Renacimiento europeo. Madrid, Alianza, 2005.

Williams, Raymond: El campo y la ciudad. Buenos Aires, Paidós, 20or. 
Calidad de Revistas

Científicas Españolas

FECYT |
SERIE III HISTORIA MEDIEVAL

REVISTA DE LA FACULTAD DE GEOGRAFÍA E HISTORIA
AÑO 2020

ISSN: 0214-9745

E-ISSN 2340-1362

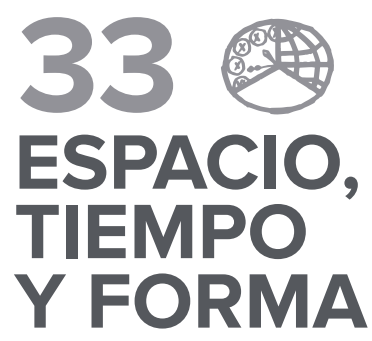

\section{Artículos · Articles}

7 FREDERIC APARISI ROMERO

El cultivo y procesado del lino en el Reino de Valencia (ss. XIII-XVII)

13 ADRIÁN CALONGE MIRANDA

El mantenimiento del entramado viario romano en época medieval en La Rioja. Algunos casos de estudio

\section{Miguel Calleja Puerta}

Notarios públicos entre dos reinos. Apuntes diplomáticos sobre documentos notariales castellanos en el Arquivo Distrital de Braga

\section{Xavier Casassas Canals}

Las 'aqida-s entre los musulmanes castellanos y aragoneses de época mudéjar y morisca: Las 'aqĩda-s de Ibn Abi Zayd Al-Qayrawāni (s. X), Ibn Tümart (s. XII) e Isa de Jebir (s. XV)

\section{ARCADIO DEL CASTILLO}

Sobre el Códice Alcobacense de Vaseo y los Annales Portugalenses Veteres: Continuidad del reino visigodo de Toledo

\section{Paula Castillo}

Las formas de la violencia entre frailes. El testimonio de Fray Ubertino de Casale

\section{María Eugenia CONTRERAS JIMÉnEZ}

La memoria del linaje Arias Dávila en la cofradía y hospital de San Cosme y San Damián de Valladolid (siglos XV a XVII)

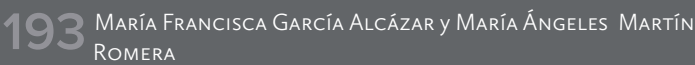
Entre servicio regio y estrategia personal: Los Continos de Valladolid (1480-1525)

\section{César García de Castro Valdés y josé Antonio Valdés
Gallego}

Las inscripciones perdidas de la basílica altomedieval de San Salvador de Oviedo

\section{María José Lop OtÍN}

Hay tal número de clérigos que causa asombro. La clerecía de Toledo a fines de la Edad Media

\section{CORINA LUCHÍA}

Por que los montes de esta villa se conserben, e no se disipen como al presente estan: La regulación de los recursos forestales en la Corona de Castilla (siglos XIV-XVI)
333 María Encarnación Martín López

Las inscripciones medievales del claustro de la catedral de Roda de Isábena (Huesca). Aproximación a su taller lapidario

\section{ISABEL MONTES ROMERO-CAMACHO}

Los archivos catedralicios y su importancia para los estudios prosopográficos. El deán Don Aparicio Sánchez, en el Archivo de la Catedral de Sevilla

\subsection{Gonzalo Oliva Manso}

La moneda en Castilla y León (1265-1284). Alfonso X, un adelantado a su tiempo.

4.73 Mariana Valeria Parma

Entre los signos del cielo y las voces de los hombres: La visión medieval del cielo y su representación apocalíptica

\section{Milagros Plaza Pedroche \\ Los maestres santiaguistas y su designación regia durante el} reinado de Juan I de Trastámara (1379-1390): La legitimación del proceso

521 Juan A. Prieto Sayagués

La profesión de las élites castellanas en los monasterios y conventos durante la Baja Edad Media

\section{EnRIQUe José RuIz PILARES}

La funcionalidad social de los inmuebles urbanos de las élites dirigentes bajomedievales: Reflexiones a partir de un caso de estudio (Jerez de la Frontera, España)

\section{Gilberto SORIANO Calvo}

Influencia de las redes nobiliarias en la expansión cristiana del siglo XII. El caso de Soria

Mohammed S. TawfiQ, AlmudenaArizaArmada, Atef Mansour Mohammad, Ahmed Ameen y Mervat Abd EL-HadyAbdEL-Latif A Historical and Numismatic Study of the Dinars of the Ghaznavid Sultan Mahmūd B. Sabuktakin at Nishapur

653 JOSÉ LUIS DE VILLAR IGLESIAS

Los aspectos económicos en la Batalla por el Magreb entre omeyas y fātimíes: El control del acceso al oro del Sudán Occidental

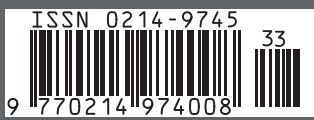




\section{3}

\section{ESPACIO,}

\section{TIEMPO}

Y FORMA

UกED

SERIE III HISTORIA MEDIEVAL

REVISTA DE LA FACULTAD DE GEOGRAFİA E HISTORIA

\section{Libros · Books}

679 Bello León, Juan Manuel y ORTEgo Rico, Pablo, Los agentes fiscales en la Andalucía Atlántica a finales de la Edad Media: Materiales de trabajo y propuesta de estudio (ANA MARÍA RIVERA MEDINA)

683 Calleja Puerta, Miguel y Domínguez Guerrero, María Luisa (eds.), Escritura, notariado y espacio urbano en la Corona de Castilla y Portugal (siglos XII-XVII) (PALOMA CUENCA MuÑoz)

687 CASADO Alonso, Hilario (coord.), Comercio, finanzas $y$ fiscalidad en Castilla (siglos XV-XVI) (ANA MARía RIVERA MEdINA)

691 Castro Correa, Ainoa y Rodríguez Sánchez, Manuel, Colección diplomática altomedieval de Galicia II. Documentación en escritura visigótica de la sede lucense (PALOMA CUENCA MUÑOZ)

695 García Fernández, Ernesto, García-Gómez, Ismael, Rodríguez FERNÁNDEZ, José, Urbanismo, patrimonio, riqueza y poder en Vitoria-Gasteiz a fines de la Edad Media e inicios de la Edad Moderna (ENRIQUE CANTERA MONTENEgRO)

699 LADERO QUESADA, Miguel Ángel, Ciudades de la España medieval. Introducción a su estudio (GISELA CORONADO SCHWINDT)

705 LADERo Quesada, Miguel Ángel, Los últimos años de Fernando el Católico 1505-1517 (CARlos Barquero GoÑI)

707 Martín GutiérRez, Emilio y Ruiz Pilares, Enrique José, El viñedo en Jerez durante el siglo XV. Un mercado de trabajo en torno al vino (ANa María Rivera MEDINA)

711 MONSALVO ANTÓN, José María, La construcción del poder real en la monarquía castellana (siglos XI-XV) (MARÍA JeSÚs FUENTE)

715 Pérez Rodríguez, Francisco Javier, Los monasterios del Reino de Galicia entre 1075 y 1540: De la reforma gregoriana a la observante (EnRIQue Cantera Montenegro)

717 REIXACH SALA, Albert, Finances públiques i mobilitat social a la Catalunya de la Baixa Edat Mitjana. Girona, 1340-1440 (JuLIÁN DONADO VARA)

721 SÁNCHEZ SÁNCHEZ, Xosé M., Iglesia, mentalidad y vida cotidiana en la Compostela medieval (ENRIQUe CANTERA MONTENEGRO)

725 Val Valdivieso, M. ${ }^{a}$ Isabel del, Martín Cea y Juan Carlos, CARVAJAL de La Vega, David (coords.), Expresiones del poder en la Edad Media. Homenaje al profesor Juan Antonio Bonachía Hernando (José RAMÓN DÍAZ DE DURANA ORTIZ DE URBINA) 